\title{
DEVELOPMENT OF REGIONAL INTEGRATION GROUPS IN THE SYSTEM OF GLOBAL TRADE AND ECONOMIC RELATIONS
}

\author{
Maryna Savchenko ${ }^{1}$, Mariia Varlamova ${ }^{2}$, Mariia Shkurat ${ }^{3}$, Leonid Melnyk $^{4}$, Victoria Bondar \\ ${ }^{1}$ Doctor of Economics, Associate Professor, Vasyl' Stus Donetsk National University, \\ 600th Annversary Street, 21-21000 Vinnytsia, Ukraine \\ ${ }^{2}$ PhD in Economics, Vasyl' Stus Donetsk National University, 600th Annversary Street, 21, 21000 Vinnytsia, Ukraine \\ ${ }^{3}$ PhD in Economics, Vasyl' Stus Donetsk National University, 600th Annversary Street, 21, 21000 Vinnytsia, Ukraine \\ ${ }^{4}$ Doctor in Economic Sciences, Associate Professor, National University of Water Management and Environmental \\ Engineering, 11 Soborna St., 33028 Rivne, Ukraine \\ ${ }^{5}$ Candidate of Economic Sciences, Odessa National Academy of Food Industry, Kanatna St., 112, 6503 Odessa, Ukraine
}

Received 0811 2020; Accepted 09122020

\begin{abstract}
The article is devoted to the problem of development of integration links between countries in the global space on the basis of the formation of trade and economic agreements. The role of regional integration processes in the world economy was described. The author's understanding of regional integration groupings is given. The evolution of international trade agreements has been determined. The leading regional integration groups in the system of global trade and economic relations reviewed. Indicators of the effectiveness of their trade and economic ties have been calculated. The stages of development of trade agreements in the world have been highlighted. On the basis of the cluster analysis, integration groups are divided into 4 groups, each of which has certain features of development. Integration groups have been found to evolve unevenly, with one cluster currently leading all the way but with a slight decline in their growth dynamics. At the same time, a cluster has been identified, the integration groups of which have the opportunity to become leaders in the future. Prospects for the development and strengthening of competitiveness in the global system of trade and economic relations have been identified for each of the selected clusters.
\end{abstract}

Keywords: integration, integration groups, trade, economic relations, regionalization.

JEL Classification: F13, F15.

\section{Introduction}

The strengthening of globalization in the twentieth century began to be accompanied by the formation of regional subsystems as components of the global trade and economic system. Regional integration groups are the centering forces that determine the development trends of trade and economic relations in the global system. In the context of globalization and the increasing interdependence of countries, when crises unfolding in one country gradually spread throughout the world, States are deepening their integration processes. This creates more sustainable regional structures in the context of economic security and competitive advantages (Popova et al., 2020). Thus, in view of the above, there has been a deepening of two- and multilateral interactions at the economic level in individual regions, which together cover almost all countries.

The intensification of regionalization processes, on the one hand, intensifies globalization processes, and on the other hand, contributes to the separation of integration formations from the world market, strengthening their independence from external demand and competitiveness.

In the context of the outbreak of trade and economic wars between countries and world instability, it is urgent to study trends in the development of regional integration processes in the global economic and trade environment.

Copyright $(C)$ 2020. Published by Vytautas Magnus University. This is an open access article distributed under the terms of the Creative Commons Attribution Non-Commercial 4.0 (CC BY-NC 4.0) license, which permits unrestricted use, distribution, and reproduction in any medium provided the original author and source are credited. The material cannot be used for commercial purposes. 


\section{Theoretical background}

Issues of international economic integration are highlighted in the works of many scholars. In particular, some aspects of economic integration are reflected in the works of Allais (1998), Barnett, Cavanagh (1995), Viner (1951), Marchall (1963), “Muller-Armack (1976), Röpke (1957), Scitovski (1958), Heilperin, (1957), Hymer (1976).

The founder of the theory of economic integration is considered to be Viner, who for the first time in the book "Questions about customs unions" (1950) systematically conducted an economic analysis of all the benefits of economic integration (Catudal, 1951). Viner (1951) divided the effects of integration into two groups: the effect of creation (tradecreation) and the effect of diversion (trade diversion). According to his research, international economic integration in most cases leads to increased prosperity for countries (Amr Sadek Hosny, 2013). The role of the scale of integration processes was also highlighted.

Further, the theory of economic integration and the impact of regional economic processes on the development of both participating countries and the world economy were complemented by researches of Marchall (1963), Allais (1998), Muller-Armack (1976), Röpke (1957), Heilperin (1957), Scitovski (1958), whose views differed, primarily in the difference in approaches to the management of integration processes - market forces or with state intervention.

Representatives of modern theories, such as Hymer (1976), Barnett (1995), link integration with the free movement of goods, labor, capital and technology within the integration association and prove the uneven development of integration processes.

Economic integration is a necessary condition for countries to promote economic growth in the context of globalization. Therefore, economic integration plays a critical role in the development strategy of many countries worldwide( Tung et al., 2020). The processes of economic integration has been strengthened in the second half of the twentieth century through the formation of two and multilateral trade and economic agreements, and caused a number of disputes due to uneven development of member countries and, consequently, various benefits from the implementation of agreements. International cooperation through trade and economic agreements has been uneven globally. To date, there have been a number of discussions on an effective model of interaction in regional trade and economic cooperation and on the role of regional integration groups in the global system of trade, economic relations and envirement (Gubanova et al., 2019).

In the studies of regional economic agreements between countries of different levels, concepts such as "trade transactions", "alliances" and "integration groups" are applied. Emphasizing at the levels and modalities of regional economic The highest levels of integration are agreements on a common market, economic and political union. Consequently, the term "trade agreements", used to characterize economic agreements between countries, limits the possibilities of integration for those agreements within which there is free movement of capital, labour force, general policy and strategy of action. However, the term "alliances" is not appropriate enough to describe agreements at the level of trade integration only. Thus, analyzing the regional economic agreements of countries, in our opinion, it is more accurate to use the term "regional integration groups" which means a set of countries in one region, interacting on the basis of multilateral agreements of different levels of economic integration.

\section{Research objective, methodology and data}

The purpose of the study is to analyse development trends and to identify the role of regional integration groups in the global system of trade and economic relations. In the process of research general scientific and empirical methods based on a systematic approach are used.

In particular, the periodization of trade agreements was determined by analysis and systematization, indicators of development of trade and economic relations of integration groups for 2000, 2010 and 2019 were calculated using economic and statistical methods, regional integration 
groups along similar lines have been implemented. The cluster analysis is carried out in two stages: the first using a tree-based clustering, as a result, based on the calculation of the distance or similarity between the indicators, the regional integration formations were grouped together. Ward's method was used to determine the degree of distance between objects. In the second stage, the K-means method was used.Data from the leading international organizations - WTO, World Bank, UNCTAD 2000-2019 - were used for the study.

\section{Results and discussion}

The first trade agreements date back to the second half of the twentieth century. Thus, the first trade agreement, which was registered in 1958, combined cooperation in the field of trade in goods and services. From 1959 to 1970 only two new agreements were concluded, from 1971 to $1980-11$, 1981-1990 - 8, 1991-2000 - 61, 2001 - 2010 - 131, 2011 - 2020 - 92 agreements (Regional Trade agreement, 2020). That is, the most dynamic trade agreements were formed at the beginning of the 21 st century, and by 2009 there was a rapid increase (the maximum number of transactions - 19 was observed in 2009).

As of 2020, according to the WTO, there are 306 existing trade agreements in the world (Fig.1).

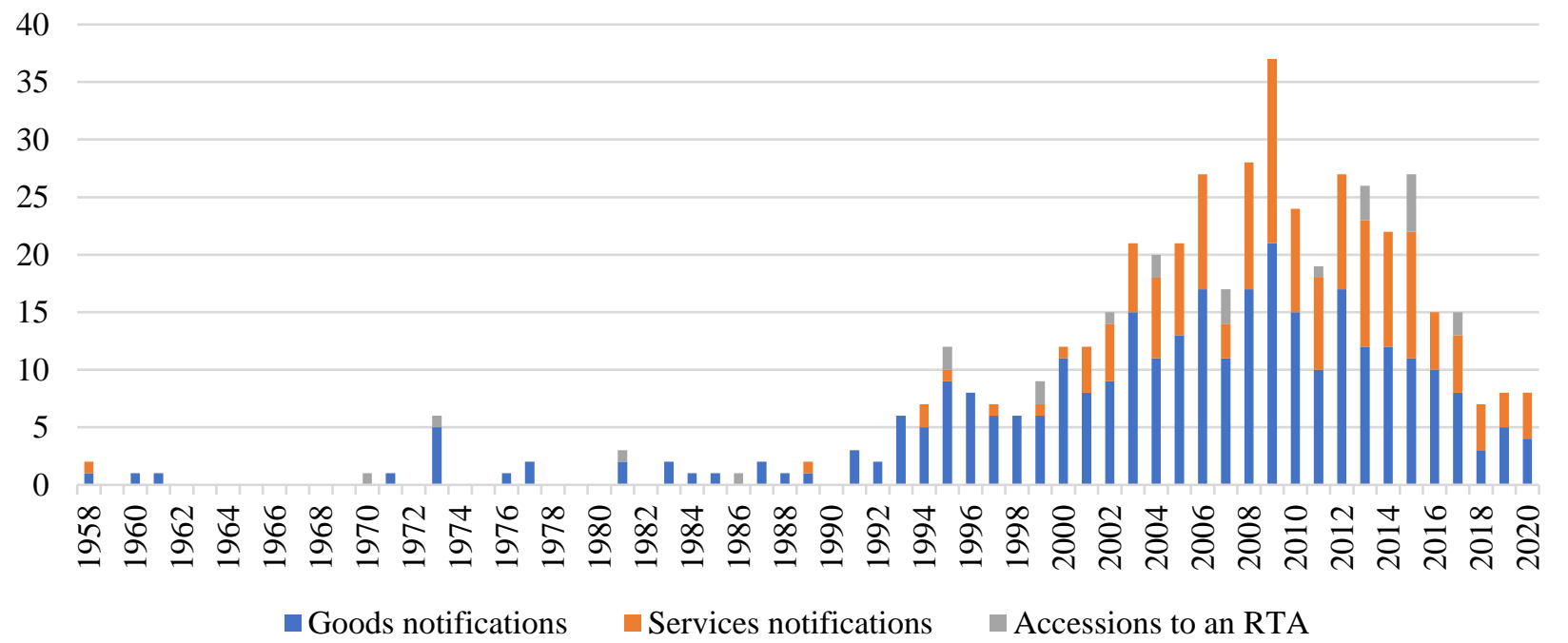

Figure 1. Dynamics of current trade agreements, 1958-2020 (September)

Source: Regional Trade agreement (2020)

It should be noted that, along with the sharp increase in the number of new transactions, there was also a rapid cessation of a significant number of commercial transactions in the 2000s (fig. 2). Thus, in 2004, a record number of trade transactions - 67 - were terminated.

So, the dynamics of trade transactions can be characterized by three stages:

1st stage (1958 - 1990) - the formation of single trade agreements.

$2^{\text {nd }}$ stage (1991-1999) - a moderate increase of trade transactions.

$3^{\text {rd }}$ stage (2000-2012) - a rapid increase in the number of new trade agreements, accompanied by the termination of many of them.

$4^{\text {th }}$ stage (2013-2020) - the rapid decline in the number of new deals, the maintenance of stable trading ties within the existing ones. 


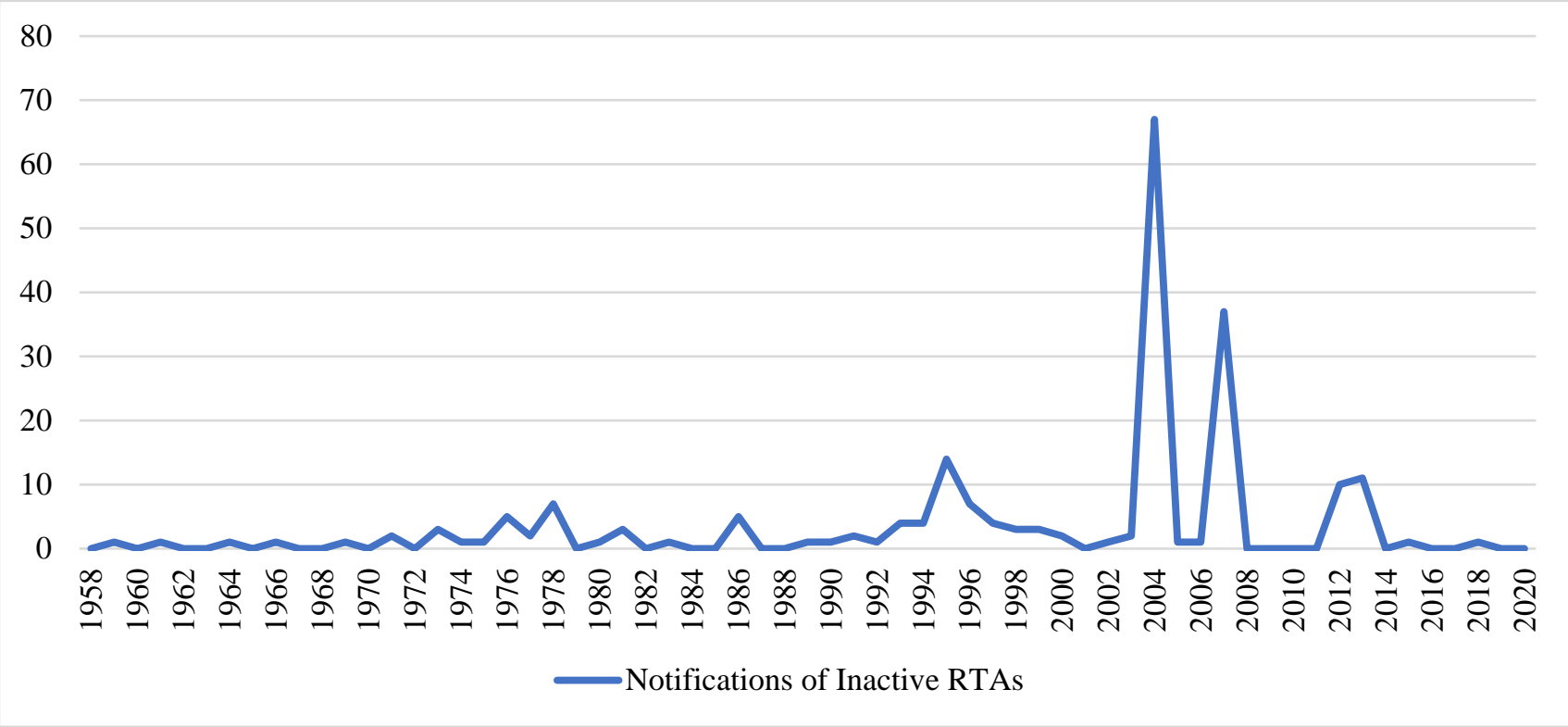

Figure 2. Dynamics of the number of terminated trade agreements, 1958-2020 (september) Source: Regional Trade agreement (2020)

One-fifth of all trade agreements are in Europe - 102 agreements, 93 agreements (18\%) - in East Asia and 66 agreements (13\%) - in South America (Fig. 3).
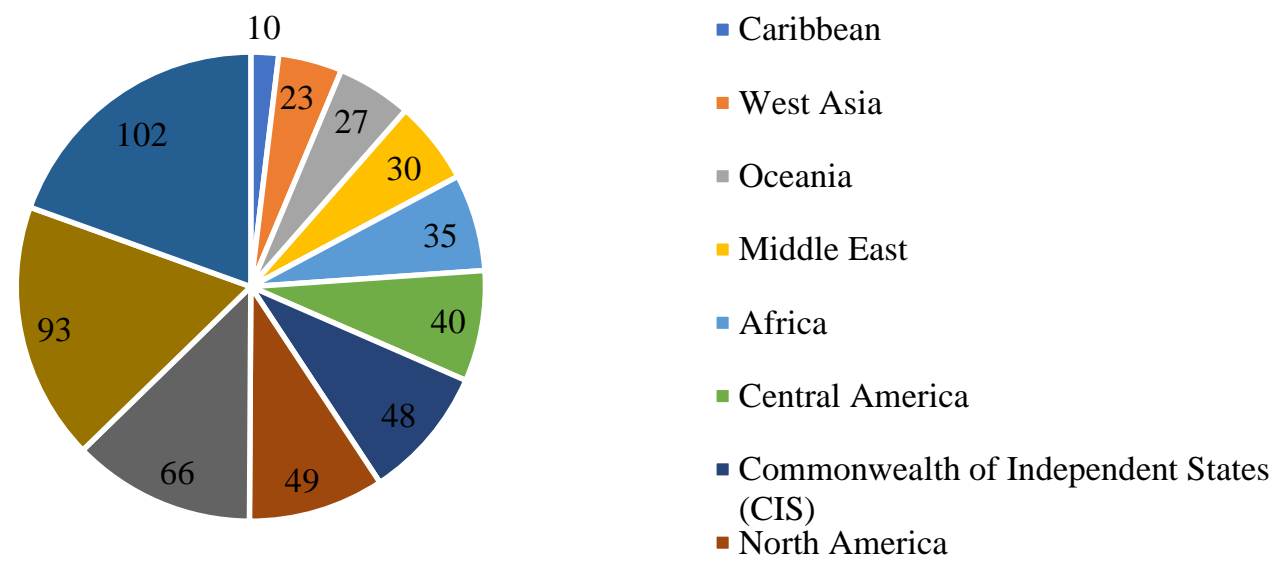

Figure 3. Notifications of RTAs in force

Source: Regional Trade agreement (2020)

Thus, half of all trade transactions are in Europe, East Asia and South America.

All these agreements can be divided into three types:

1) multilateral agreements, that form a regional grouping, between the participants of which preferential trade relations are established. These relationships are more profitable than the most-favored-nation treatment.

2) bilateral agreements between individual countries;

3) bilateral agreements between individual countries and regional groups .

Among the most significant WTO multilateral regional trade groups for 2020, the following stand out (Table 1). 
Table 1. Distribution of regional integration groups

\begin{tabular}{|l|l|}
\hline \multicolumn{1}{|c|}{ Region } & \multicolumn{1}{c|}{ Integration grouping } \\
\hline America & $\begin{array}{l}\text { 1. Andean Community (ANDEAN) Caribbean Community (CARICOM) Central American } \\
\text { Common Market (CACM) } \\
\text { 2. North American Free Trade Agreement (NAFTA) } \\
\text { 3. Southern Common Market (MERCOSUR). }\end{array}$ \\
\hline Asia & $\begin{array}{l}\text { 1. Association of Southeast Asian Nations (ASEAN) } \\
\text { 2. South Asian Association for Regional Cooperation (SAARC) } \\
\text { 3. Gulf Cooperation Council (GCC) }\end{array}$ \\
\hline Europe & 1.European Union (EU) \\
& 2.European Free Trade Association (EFTA) \\
& 1. Central African Economic and Monetary Community (CAEMC) \\
& 2. Economic Community of West African States (ECOWAS) \\
& 3. Common Market for Eastern and Southern Africa (COMESA) \\
& 4.West African Economic and Monetary Union (WAEMU) \\
& 5. Southern African Development Community (SADC) \\
\hline
\end{tabular}
Source: World Trade Statistical Review (2020)

The extent of trade transactions of integration groups is illustrated by export and import indicators (fig. 4-5).

As shown in figure 4, the exports of the groups have grown dynamically since 2000-2019, but the gap between the EU, NAFTA and other groups is widening.

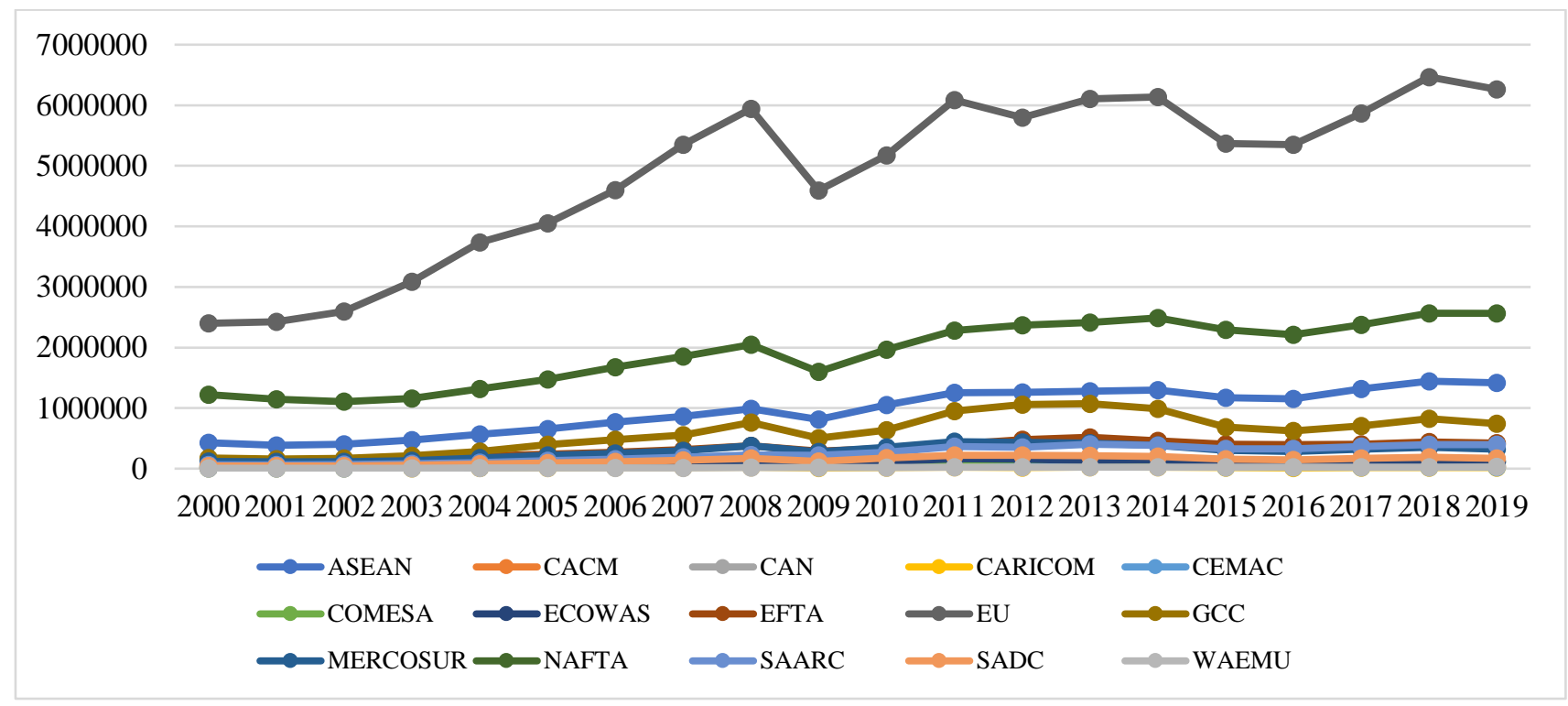

Figure 4. Dynamics of exports of regional integration groups for 2000-2019, million dollars USA (Unctadstat, 2020)

A similar trend is taking place in imports. 


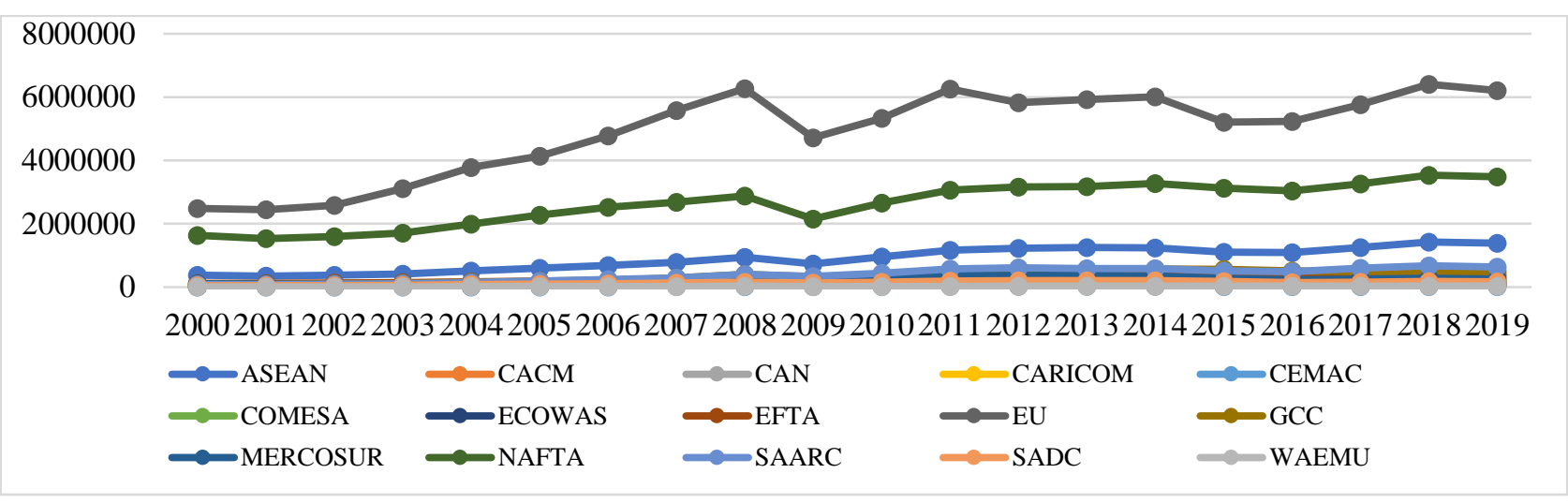

Figure 5. Dynamics of imports of regional integration groups for 2000-2019, million dollars USA (Unctadstat, 2020)

We will use the approaches of the World Bank (2020) and UNCTAD (2020) to analyse the development trends of these regional integration groups. Among the many indicators that characterize the state of international trade and economic relations as an element of the global system, we will highlight the most important of them. In particular, these are such quantitative indicators of international trade as economic openness, the share of the region's GDP in gross world product, the share of intra-trade in total trade with all countries, the share of intra-trade in total trade within the region. The indicator of economic openness is used in World Bank methodologies. The openness of the economy of an integration grouping in the global system of international trade means that such grouping has stable economic and trade links in the system of international trade and economic relations. The Mutual Trade Importance Indicator shows the share of intra-regional trade of the countries in the regional formation in relation to total exports and imports. An indicator of the scale of the economy of a regional integration grouping is its share in world GDP. For each of the listed regional integration groups, the indicators as of 2019 have been calculated (Table. 2).

The economies of ASEAN and GCC are the most open, given the development of trade relations, but for ASEAN, the opening index for 2000-2019 is declining.

Table 2. Indicators of development of regional integration groups, 2019

\begin{tabular}{|l|c|c|c|c|c|}
\hline \multirow{2}{*}{$\begin{array}{c}\text { Regional } \\
\text { integration } \\
\text { grouping }\end{array}$} & $\begin{array}{c}\text { Index of } \\
\text { economic } \\
\text { openness }\end{array}$ & $\begin{array}{c}\text { The share of the } \\
\text { grouping's GDP } \\
\text { in world GDP, } \%\end{array}$ & $\begin{array}{c}\text { Share of intra trade in } \\
\text { general trade turnover } \\
\text { with all countries of the } \\
\text { world, } \%\end{array}$ & $\begin{array}{c}\text { Share of intra } \\
\text { trade in total trade } \\
\text { within the } \\
\text { region, } \%\end{array}$ & $\begin{array}{c}\text { Share of trade in } \\
\text { total world } \\
\text { trade, } \%\end{array}$ \\
\hline ASEAN & 1,01635 & 3,618942 & 22,90671 & 32,32186 & 22,90671 \\
\hline CACM & 0,668999 & 0,237082 & 17,61236 & 23,93078 & 17,61236 \\
\hline $\begin{array}{l}\text { Andean } \\
\text { Community }\end{array}$ & 0,376812 & 0,794871 & 7,038142 & 14,07707 & 7,038142 \\
\hline CARICOM & 0,613949 & 0,094974 & 9,442251 & 14,16692 & 9,442251 \\
\hline CEMAC & 0,67528 & 0,108478 & 3,30797 & 32,59397 & 3,30797 \\
\hline COMESA & 0,492356 & 1,010092 & 7,038219 & 49,09115 & 7,038219 \\
\hline ECOWAS & 0,398206 & 0,795859 & 8,297983 & 63,16155 & 8,297983 \\
\hline EFTA & 0,570235 & 1,309538 & 0,551444 & 0,92358 & 0,551444 \\
\hline European Union & 0,617232 & 20,88945 & 61,13925 & 89,46223 & 61,13925 \\
\hline GCC & 0,8639 & 1,875067 & 11,17176 & 16,32942 & 11,17176 \\
\hline MERCOSUR & 0,208777 & 3,124783 & 12,93394 & 34,70818 & 12,93394 \\
\hline NAFTA & 0,260327 & 27,98819 & 40,13524 & 88,07679 & 40,13524 \\
\hline SAARC & 0,348021 & 4,295345 & 5,695077 & 10,09749 & 5,695077 \\
\hline SADC & 0,531265 & 4,295345 & 19,55438 & 84,94278 & 19,55438 \\
\hline WAEMU & 0,539789 & 0,147633 & 11,06866 & 48,51825 & 11,06866 \\
\hline
\end{tabular}


(figure 6).

The least open of the regional integration groups analysed is the MERCOSUR economy

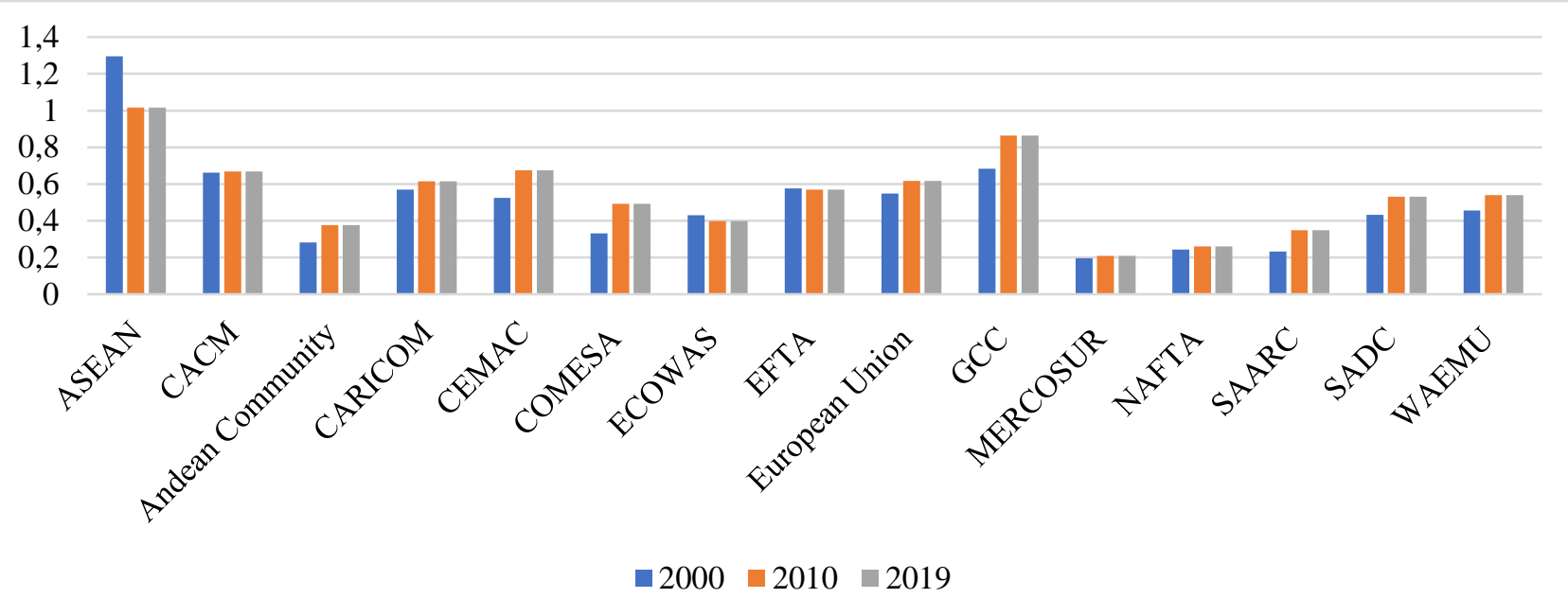

Figure 6. Dynamics of the Openness Index of the Economy for 2000, 2010, 2020

Source: calculated by the authors according to Unctadstat (2020)

For most integration groups, sustainable economic and trade linkages in international economic and trade relations are increasing. For most integration groups, sustainable economic and trade linkages in international economic and trade relations are increasing.Considering the share of GDP of regional integration groups in world GDP, we should distinguish two integration groups - the EU and NAFTA, which form almost half of world GDP (Fig. 7). Their share is $20.8 \%$ and $27.9 \%$ respectively. But it is their shares that have declined significantly over the period 2000-2019. Thus, this indicator for NAFTA in 2000 was 35\%. However, for most other regional groups there is an increase in this indicator - for ASEAN the growth rate was 195\%, SADS - 230\% (based on UNCTAD).

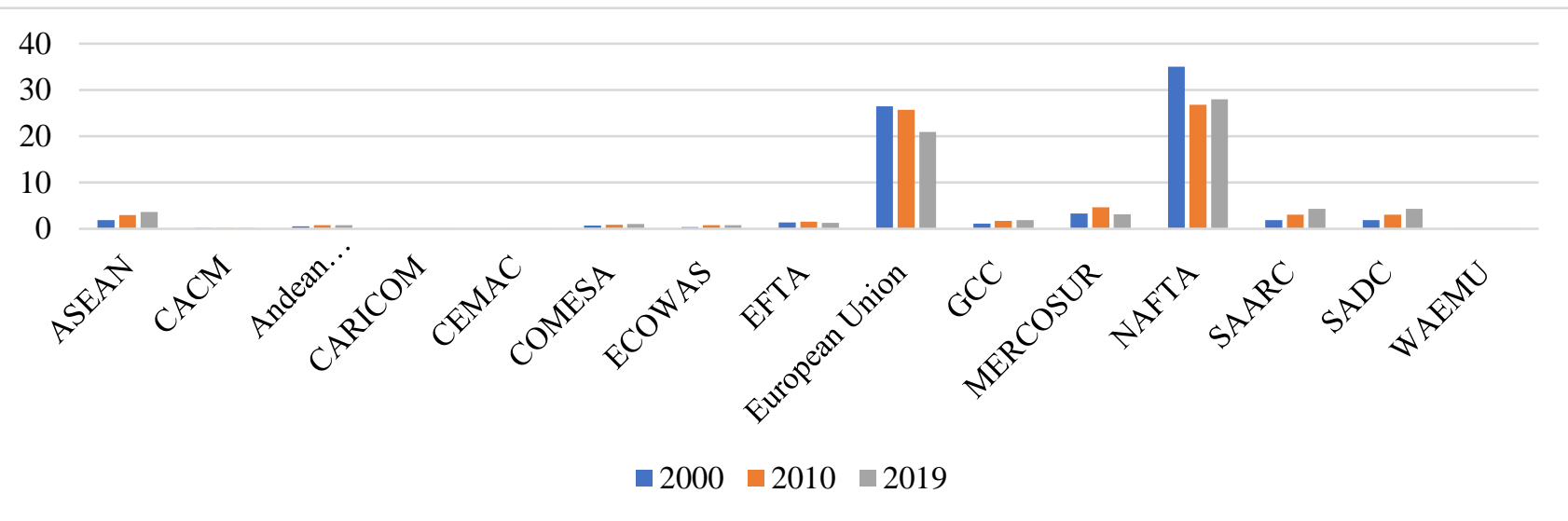

Figure 7. Dynamics of the share of GDP in world GDP, \%

Source: calculated by the authors according to Unctadstat (2020) 
Analysis of the share of intra-trade shows that within the world there is a significant concentration of trade relations within the integration groups. For the EU, $61 \%$ of all trade relations account for trade between EU member states, for NAFTA - 40\%, for ASEAN - 23\%, for SADS 20\% (Fig. 8).

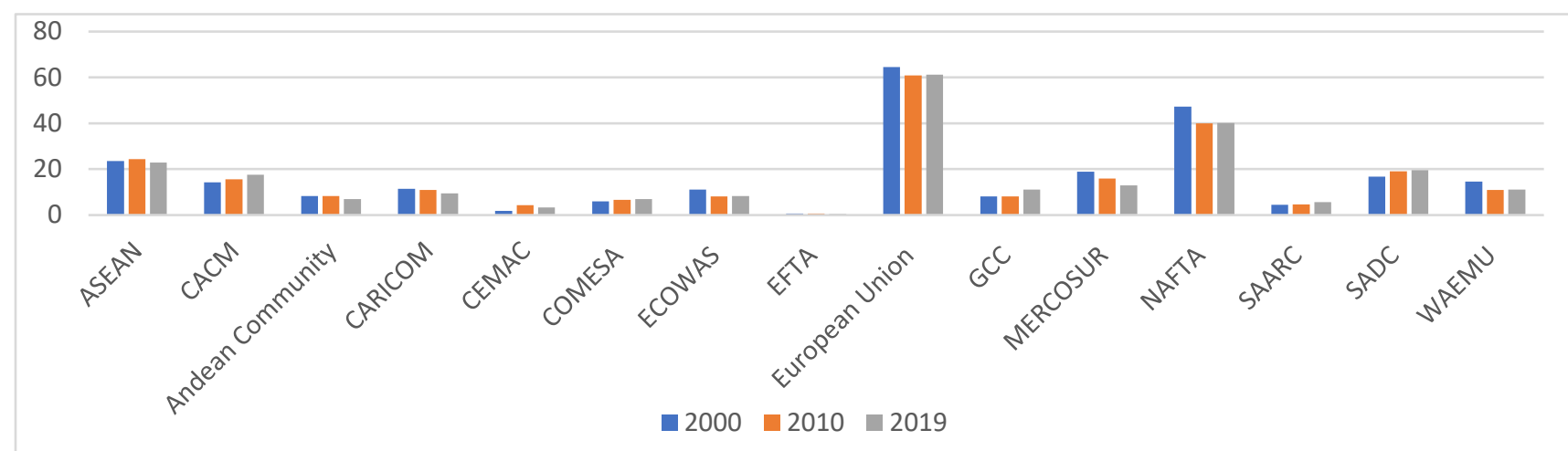

Figure 8. Dynamics of the share of intra-trade in total trade with all countries, $\%$ Source: calculated by the authors according to UNCTAD

An even higher concentration of trade is observed within the region (Fig. 9).

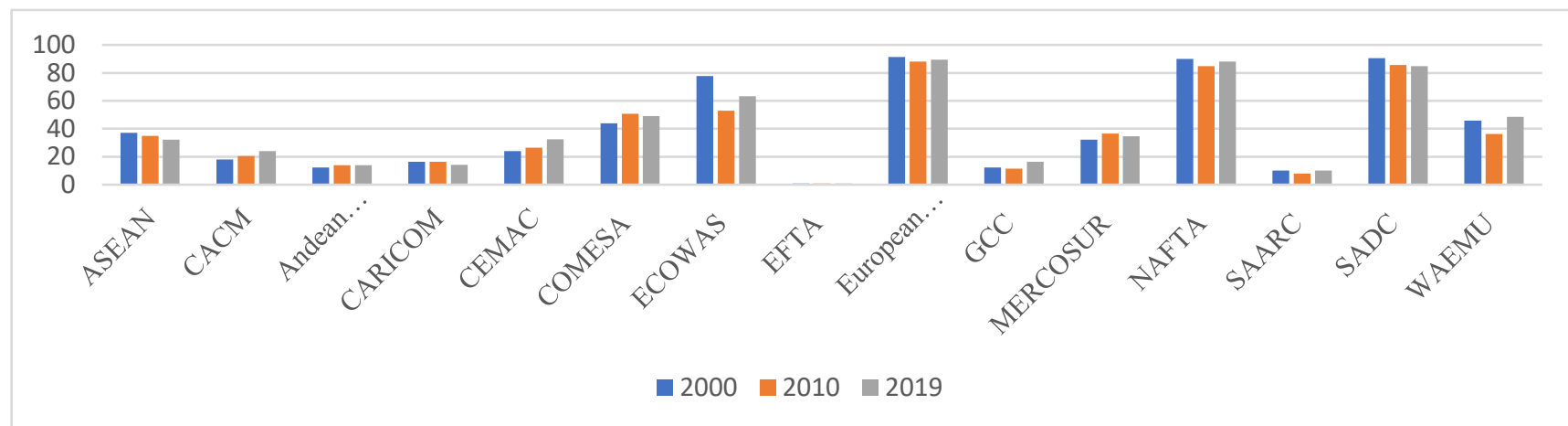

Figure 9. Share of intra-trade in total trade within the region (Asia, Europe, America, Africa), \%

Source: calculated by the authors according to Unctadstat (2020)

For the EU 89, $4 \%$ of trade relations in Europe are concentrated within the integration grouping, for NAFTA - 88\%, for SADS - 85\%, for ECOWAS - 63\% (based on UNCTAD). For SAARC, EFTA, GCC, ANDEAN, there is a slight impact of integration opportunities on the formation of trade relations in a particular region.

In order to highlight the common features of the development of regional integration groups, they have been divided into groups through clustering. The following data were selected for cluster analysis (Yankovyi et al., 2020):

- $\quad$ share of intra-trade in general trade with all countries of the world;

- share of intra-trade in total trade within the region,

- share of GDP of the regional integration group in world GDP;

- share of foreign direct investment (inflow) in regional integration groups in the world volume of foreign direct investment (inflow);

- share of foreign direct investment (outflow) in regional integration groups in the world volume of foreign direct investment (outflow).

In the first phase, tree clustering was used to combine regional integration formations into groups based on calculation of distance or similarities between indicators. The Ward method is used to determine the distance between objects. The results show four clear clusters (Figure 10), grouping regional integration groups with certain similarities. 


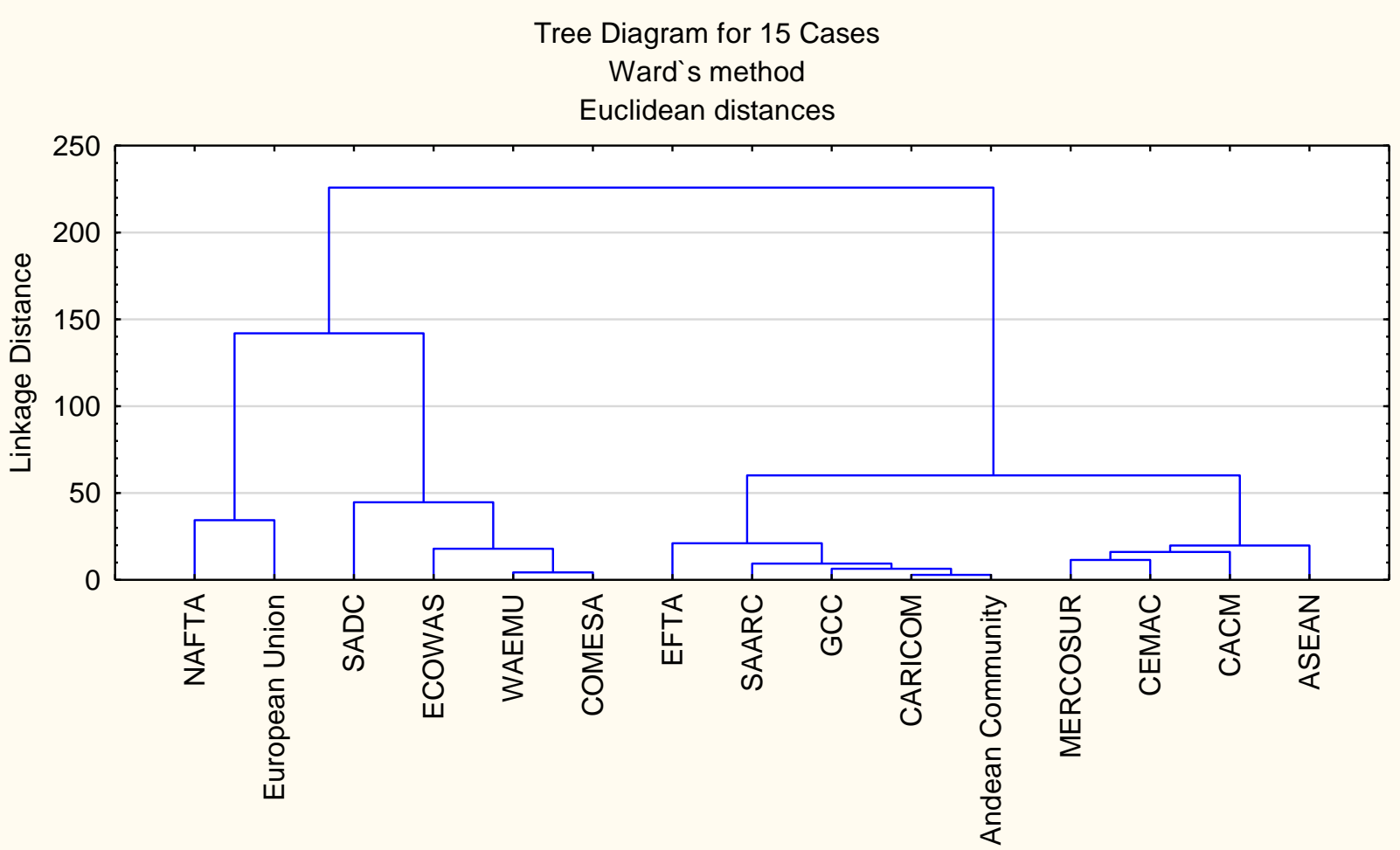

Figure 10. Vertical dendogram tree clustering of regional integration formations

Source: calculated by the authors

To carry out clustering, we use the method of k-means, the purpose of which is to divide nobservations from the set $R^{n}$. into k-clusters. In this case, each observation refers to the cluster to the center (centroid) of which it is closest.

Euclidean distance is used as a measure of proximity:

$$
p(x, y)=\|x-y\|=\sqrt{\stackrel{̊}{a}_{p=1}^{n}\left(x_{p}-y_{p}\right)^{2}},
$$

where $x, y$-observations that belong to the set $R^{n}$.

Thus, the essence of the method $\mathrm{k}$ - means lies in the dividing of $n$ - observations on $k$-g (або кластерів), where ( $k £ n)$, а саме $S=\left(\mathrm{S}_{1}, \mathrm{~S}_{2}, \ldots, \mathrm{S}_{k}\right)$,

The purpose of this is to minimize the total quadratic deviation of the points of the clusters from the centroids of these clusters. The results of clustering by the method averages are presented in Fig. 11 - 12. 


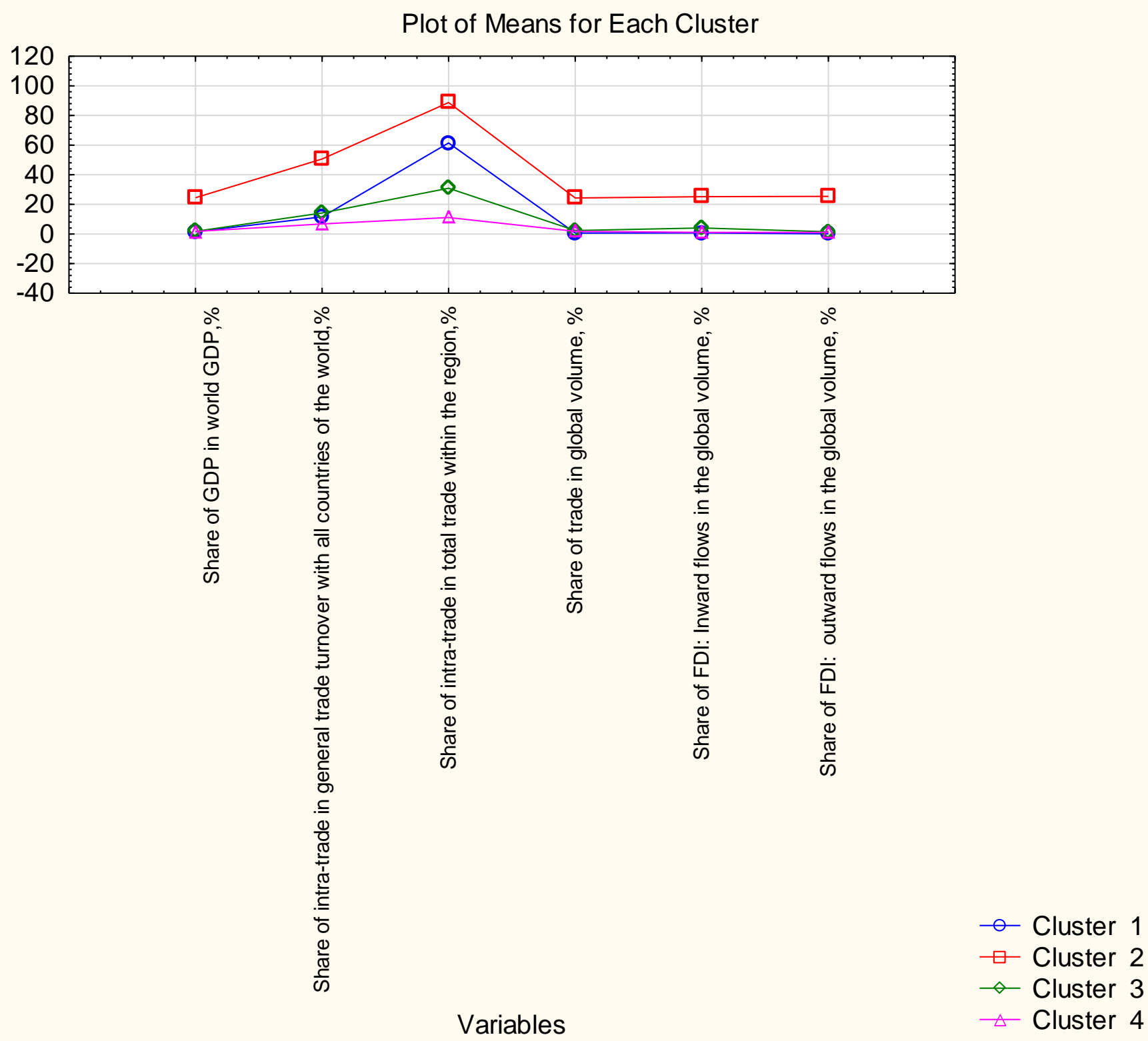

Figure 11. Graph of average values of variables for each cluster

Source: calculated by the authors

The list of observations included in each of the clusters is shown in Fig. 12

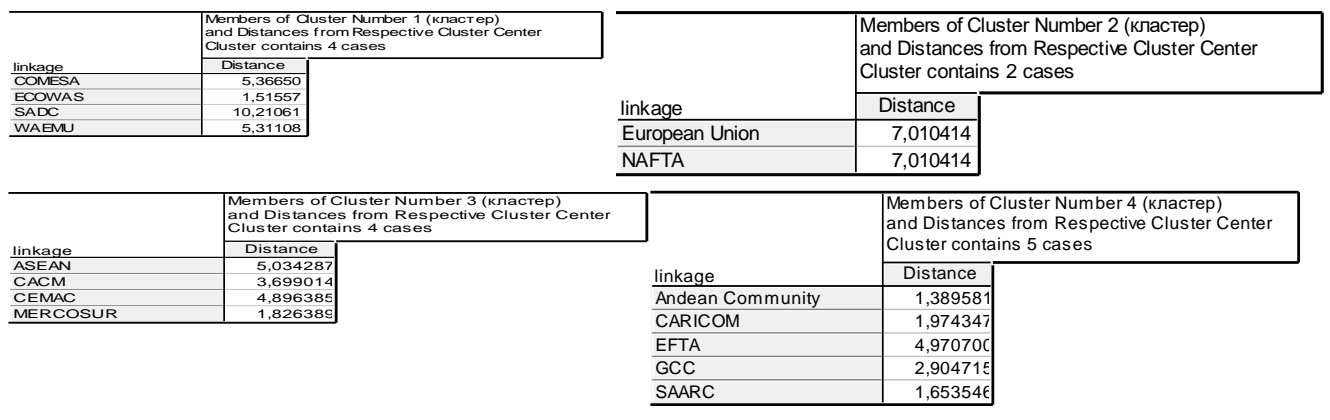

Figure 12. Observations included in 1,2,3, 4 clusters, respectively

Source: calculated by the authors 
The first cluster is formed by such integration groups as COMESA, ECOWAS, SADS, WAEMU. All of them belong to the African region and have the following features: the share of trade between member countries in the total trade of the regional integration group within the region is quite high and ranges from 2019 to $48 \%$ to $85 \%$, but the total share of trade groups is relatively small, ranges from 0.2 to $0.9 \%$. Also, the GDP of these groups and FDI flows in global volumes are less than $1 \%$.

The European Union and NAFTA, groups from different regions of the world, form the second cluster and differ significantly in terms of indicators from all other regional integration groups. The peculiarity of the cluster - the highest concentration of trade within the integration grouping almost $90 \%$ of all trade transactions carried out in the regions (Europe and America, respectively) are between the participating countries. In addition, $40 \%$ of NAFTA trade in total foreign trade and 61 $\%$ of EU trade in NAFTA also takes place within integration groups .These two integration groups are characterized by the highest share of trade and foreign direct investment in the world.

Thus, the development of integration processes for regional groups has the effect of reorienting trade from third countries to the countries of the integration grouping.

The third cluster is formed by groups from three regions of the world (Asia, America and Africa) - ASEAN , CACM, CEMAC and MERCOSUR.

The share of trade of integration groups with the countries of their region ranges from $24 \%$ to $35 \%$

The fourth cluster is formed by Andean Community, CARICOM, EFTA, GCC, SAARC. The share of their trade with the countries of the base region is much smaller, ranging from $1 \%$ to $14 \%$. Accordingly, in the group's total foreign trade, the share of trade transactions between member countries is quite small - from $0.5 \%$ to $9 \%$ (based on UNCTAD). Consequently, the share of trade between the countries involved in the total volume of foreign trade of the grouping is very small from 0.5 to 9 per cent. It should be noted that these integration groups are significantly inferior in terms of performance to the other integration groups formed in these regions, which are in other clusters.

Thus, as of 2019, regional groups such as NAFTA and the EU are leading the global system of international trade and economic relations. Accordingly, they will determine the trends in these relations in the near term.

At the same time, the influence of the integration groups of the third cluster, especially ASEAN and MERCOSUR, is gradually increasing. In the American region, MERCOSUR now ranks second to NAFTA, and if the free trade zone agreement is ratified with the EU, it will be possible to significantly deepen its trade and economic ties. ASEAN is at the forefront of the Asian region and is in the process of establishing Comprehensive Regional Economic Partnership, which includes, in addition to the existing ASEAN countries, Australia, China, India, Japan, New Zealand and South Korea. If we consider the current results of cooperation within ASEAN + 3 (+ China, Japan, South Korea), it should be noted that ASEAN + 3 in terms of trade in 2019 is significantly ahead of NAFTA (Fig. 13).

At the same time, in 2000, NAFTA trade outpaced ASEAN + 3. Growth rates in 2019 compared to 2000 for these groups were $212 \%$ and $399 \%$, for the EU - 255\% (UNCTAD). The growth rate of ASEAN +3 is almost twice ahead of the leading integration groups. Thus, with the strengthening of integration in this region, Asia's influence on the global system of trade and economic relations is growing. 


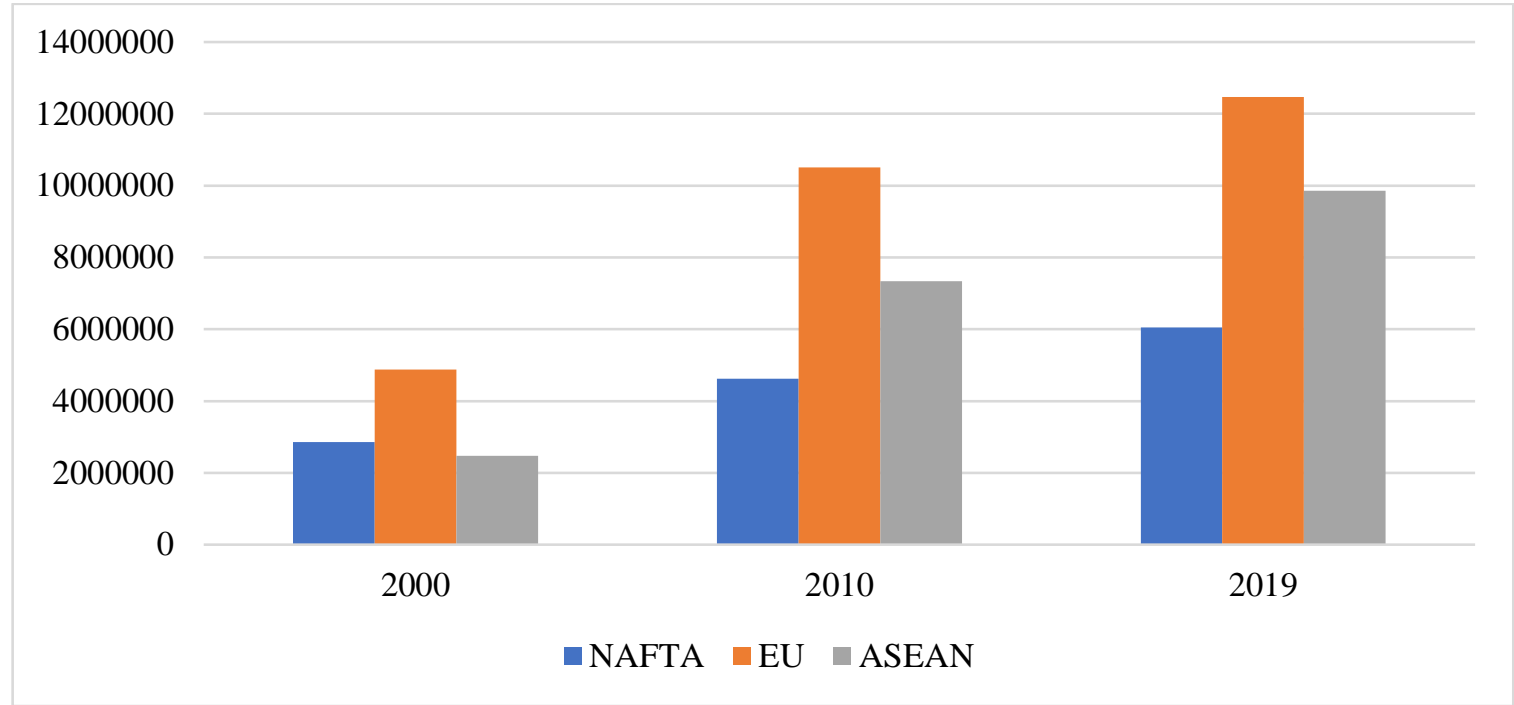

Figure 13. Dynamics of foreign trade turnover NAFTA, EU, ASEAN + 3

Source: calculated by the authors according to Unctadstat (2020)

So, strengthening competitiveness of this cluster is possible in the future through the strengthening of integration processes based on groups, which is already taking place today and confirmed at the level of supplementary agreements. At the same time, ASEAN is actively strengthening its leadership position globally, threatening to weaken NAFTA's leadership. MERCOSUR, CACM and CEMAC are enhancing regional competitiveness through separate trade agreements with other integration groups. With regard to the first cluster presented by COMESA, ECOWAS, SADS, WAEMU, it should be noted that, for the time being, these integration groups have no significant impact on the development of the global system of trade and economic relations, but there is a significant impact on the development of trade relations in the region.

The groups of the latter cluster have less scope for economic development and may become uncompetitive in the global system of international economic and trade relations and, as a result, the terms of their interaction may disappear or be redefined, in particular with countries outside the groups . The consolidation of subregional integration groups is promising. The African Continental Free Trade Area, which has one of the largest member countries in the world, has now been signed. With the harmonization of the legal framework of the participating countries and in the case of establishing a mechanism of cooperation, Africa's income is expected to increase by $\$ 450$ million. US by 2035. Of this, $\$ 292$ million the United States is expected to gain more from trade facilitation (World Bank, 2020). Thus, in modern conditions, increasing competitiveness in the global system of trade and economic relations becomes possible by strengthening integration cooperation at the regional level and creating strong regional integration groups.

\section{Conclusions}

The analysis revealed that among the integration groups that dominate the global system of trade and economic relations, two leaders stand out - NAFTA and the EU - accounting for 49 per cent of world trade. However, their pace of trade development lags behind that of ASEAN. New agreements based on the latter indicate the likelihood of further leadership of the regional group of Asia. The cluster analysis identified four groups of integration groups, one of which included the above leaders. The peculiarity of the development of their trade and economic relations is the concentration of about 90 per cent of regional trade between the member countries of the integration grouping, and about 40 per cent for NAFTA and 61 per cent for the EU of their total foreign trade. Thus, there is a significant effect of «creation» of trade from the functioning of regional integration groups . 
Based on the results of the analysis, it is possible for integration groups with high international trade performance to become more competitive in the global system of trade and economic relations, measures in foreign trade are strengthened with low-performing integration groups and through cooperation with high-performing regional groups. For regional integration groups with low numbers of indicators of international trade, measures to improve the legislative framework, promote the development of entrepreneurship and modernize production are relevant, first of all. In fact, most of their member states have mostly low levels of production Second, it is promising to merge with subregional integration groups, that creating opportunities to enhance competitiveness in the global trading and economic system. Thus, the research carried out illustrate the increased development of trade links through regional integration groups and the possibility of increasing global competitiveness through deeper linkages within the region, in particular the expansion of regional integration groups.

\section{References}

Allais, M. (1998). Terms of efficiency in the economy. M.: Scientific Publishing Center" Science for Society.

Amr Sadek Hosny (2013). Theories of Economic Integration: A Survey of the Economic and Political Literature // International Journal of Economy, Management and Social Sciences, Vol. 2(5): 9-17.

Barnett, R., Cavanagh, J. (1995). Global dreams: Imperial corporations and the new world order. New York: Simon and Schuster

Catudal, Honore M. (1951). Review of The customs union issue, by Jacob Viner // The American Journal of International Law, Vol. 45 (1): 209-211.

Dovhal, O.A., Kazakova, N.A. (2018). Hlobalizatsiia ta rehionalizatsiia yak vektory rozvytku mizhnarodnykh ekonomichnykh vidnosyn [Globalization and regionalization as vectors of development of international economic relations]. Kharkiv: V. N. Karazin Kharkiv National University (in Ukrainian).

Gubanova E., Kupinets L., Deforzh H., Koval V., Gaska K. (2019). Recycling of polymer waste in the context of developing circular economy // Architecture Civil Engineering Environment, vol. 12(4): 99-108. doi: 10.21307/ACEE2019-055

Heilperin, M. A. (1957). Free trade and social welfare // International labour review, March, 173-192

Hymer, S. (1976). The international operations of national firms: a study of direct foreign investment. Boston:MIT Press.

Marchal, A. (1965). Europe solidaire // Revue économique, Vol. 1-2: 341-345.

Muller-Armack, A. (1976). Wirtschaftsordnung und wirtschaftspolitik. studien integration. Bern: Rombach.

Perroux, F. (1966). Integration economique. "Qui integegree? Au benefice de qui s'opere l'integration?"// Economie apliquee. Tome XIX, vol. 3-4: 400.

Popova, O., Koval, V., Mikhno, I., Tarasov, I., Asaulenko, N., Filipishyna, L. (2020). Assessments of national tourism development in terms of sustainability and inclusiveness // Journal of Geology, Geography and Geoecology, vol. 29 (2): 377-386. https://doi.org/10.15421/112033.
Regional trade agreements
(2020).
WTO
Database.
Retrived
from http://rtais.wto.org/UI/PublicMaintainRTAHome.aspx\#.

Röpke, W. (1957). Integration und desintegration der internationalen wirtschaft: in Wirtschaftsfragen der freienWelt. Frankfurt: Fritz Knapp.

Scitovski, T. (1958). Economic theory and western European integration. London: George Allen and Unwin

Shnyrkov, O.I, Filipenko, A.S., Zablotska, R.O. (2016). Rozvytok novitnikh form mizhnarodnoi ekonomichnoi intehratsii na pochatku XXI stolittia [Development of new forms of international economic integration at the beginning of the XXI century]. Kyiv: Publishing and printing center "Kyiv university" (in Ukrainian)

Sidenko, V.R. (2003). Ukraina v protsesakh mizhnarodnoi intehratsii [Ukraine in the processes of international integration]. Kharkiv: Fort (in Ukrainian).

Tung, L., Thang, P., Uyen, L. (2020). Does economic integration affect inequality in developing countries? Evidence from a global sample// European Journal of Sustainable Development, vol. 9 (2): 579-588. doi: 10.14207/ejsd.2020.v9n2p579.

Timbergen, J. (1965). International economic integration. Amsterdam: Elsevirer.

Unctadstat (2020). SDG Trade Monitor. Retrived from https://unctadstat.unctad.org.

World Trade Statistical Review (2020). Retrived from https://www.wto.org.

Worldbank. (2020) Data bank. Retrived from https://databank.worldbank.org.

Yankovyi O., Koval V., Trokhymets O., Karpenko M., Matskevich Y. (2020). Economic assessment of investment on the basis of production functions. Turismo: Estudos \&Práticas, 2. 